\title{
Libyan Construction Projects Delivery Systems: Empirical Comparison Between Design-Build and Design-Bid-Build
}

\author{
Medhat Abdelrahman Youssef ${ }^{1, ~}$,,Gamal Abukhder ${ }^{2}$, Abdelhamid S. A. Gliah ${ }^{2}$ \\ ${ }^{1}$ Dept. of Construction Management and Utilities, Faculty of Engineering, Zagazig University, Egypt \\ ${ }^{2}$ Libya Academy of Post Graduate Studies, Department of Engineering Management, Tripoli, Ganzor, Libya \\ Email address: \\ med_most@yahoo.com (M. A. Youssef), jamalsmt@yahoo.co.uk (G. Abukhder), abdalhamidglia@yahoo.com (A. S. A. Gliah) \\ ${ }^{*}$ Corresponding author
}

\section{To cite this article:}

Medhat Abdelrahman Youssef, Gamal Abukhder, Abdelhamid S. A. Gliah. Libyan Construction Projects Delivery Systems: Empirical Comparison Between Design-Build and Design-Bid-Build. Engineering and Applied Sciences. Vol. 2, No. 1, 2017, pp. $17-21$.

doi: $10.11648 /$ j.eas.20170201.12

Received: January 9, 2017; Accepted: January 25, 2017; Published: May 2, 2017

\begin{abstract}
Projects delivering on time and budget is still complex. This study presents actual project performance comparisons of the Design-Bid-Build "DBB" and Design-Build "DB" systems into Libyan projects. By analyzing 124 projects delivered by two methods and two types of companies (local and foreign) to provide objective comparison of cost and schedule performance. The results show that average DB cost was about 1.45 times larger than DBB. The project achieved by local and foreign companies, average cost overrun for DBB was $34 \%$, and $26 \%$ respectively, Whilst only $10 \%$ and $0 \%$ for DB for local and foreign companies. The average time extension by local and foreign companies for DBB was $39.8 \%$, and $43 \%$, whilst only $32 \%$ and $0 \%$ for DB for local and foreign companies. DB projects executed by foreign company had little change order than DBB. This paper compares two project delivery systems, namely Design-Bid-Build and Design-Build, as well as two types of construction companies, local and foreign. Data for 124 projects were collected from Libyan Audit Bureau. In terms of the construction time and cost, the paper concludes that the foreign companies did a better job than the local companies. Also, provides quantitative data to support the delivery system selection with understanding its performance criteria.
\end{abstract}

Keywords: Project Delivery Systems, Design/Build, Design/Bid/Build, Construction Cost Overrun, Project Time Delay, Time Performance, Cost Performance

\section{Introduction}

Construction industry has played a significant and distinct role in Libya; The Libyan construction industry contributes more to the country's economy than do manufacturing or other services industries. The construction industry is a benchmark for economic growth for other sectors. The success of a construction project was often impacted by the project delivery system used [1]. There are several methods and combinations of methods an owner can choose from to deliver a project. Each method has distinct advantages and disadvantages for both the owner and the contractor. The main reason of construction activity is to develop infrastructure of the country for more investments and contribute in increasing the national income [2]. Construction is unique in that it can stimulate the growth of other industrial sectors. Construction contractors are required to build products efficiently and cost effectively, to satisfy owner requirements. Yet, these requirements generally change during the project duration due to advances in technology, change in focus, refinement of design, better understanding of what is needed, and economic factors [3]. The construction industry has been searching for effective project delivery methods to maximize project performance over the past decades among the available different delivery systems such as design-bid-build (DBB), and design/build (DB). Design Build system is widely used in many countries.

The scope and purpose of this study were analyzed empirical projects data for two samples. Firsts ample contains 81 DBB Libyan construction projects and the second contains 43 DB Libyan construction projects. Analyses used to measure cost and schedule performance of projects and perform an empirical comparison of DBB and $\mathrm{DB}$ with respect to time and cost changes. Also, compare 
between projects time and cost changes for local and foreign construction companies.

\section{Literature Review}

A Project Delivery System that can achieve certain project objectives better than others may also perform worse on some other objectives. No single Project Delivery System is appropriate for all types of projects under all circumstances [4]. The length of time to complete a project is an important element of project performance. Time and cost overruns on infrastructure development projects during implementation continue to pose great challenges to developing countries. Delays and cost overruns in public sector investments can raise the capital-output ratio in the sector and elsewhere bringing down the efficacy of investments [5]. Project's cost overrun, delays, and unqualified quality during practical engineering activities refer to an improper project delivery system selection at the beginning of a project [6].With respect to the owner, time overrun (delay) means loss of revenue through lack of production facilities and rent-able space or a dependence on present facilities [7].

There are several definitions of project delivery system in Libyan construction industry. Design-bid-build and Design build are the most commonly project delivery system used in Libya. All project delivery systems definitions describe "the sequencing of design, procurement, and construction, and define the roles of participants, the relationships between them, both formal and informal, the timing of events and the practices and used management techniques" According to [8, 9, 10 and 11]. Esmaeiliet. al. [11],present a summary of critical success factors for different project delivery methods. Time performance of DB projects was a good, more than $75 \%$ completed on time, or ahead of schedule [12]. Konchar and Sanvido [13], compare the cost, schedule, and quality performance of three project delivery systems (DB, construction management at risk, and DBB), for 155 DB projects. Finding the median cost and schedule growth were be $2.17 \%$ and $0 \%$ respectively, also $5.2 \%$ and $11.4 \%$ less than DBB projects. Hale et al. [14],study of 39 DB project, cost and schedule growth were an average $2 \%$ and $11.5 \%$ respectively less than DBB projects.

\section{Methodology}

A review carried on 124 construction projects with different types, size, location and Construction Company "local or foreign". The cases studied presents a sample of projects, which completed on the last twenty years. Information about the amount of time and cost changes during the project delivery collected through studying the project documents histories. The change in cost defined as the difference between the final cost at the project completion and the initial budget. Also, the change in schedules was defined as the difference between the time used to complete the project and the initial project scheduling as shown in equation (1\&2) [9]. The project performance indicators cost and time is the only criteria, which measured directly, time and cost are the fundamental norms of measuring project success. Completion of any project within estimated time reflects the efficiency of the construction crew through the construction process [15]. Primary data obtained from 124 projectdocuments. The collected data analyzed and the results showed in graphs. Two project delivery systems mentioned previously, design-build and design-bid-build compared in this research.

$$
\begin{gathered}
\text { Cost Change }=\left[\frac{(\text { final } \cos t-\text { initial budget })}{\text { initial budget }}\right] \times 100 \\
\text { Schedule Change }=\left[\frac{(\text { total time used }- \text { initial estimated time })}{\text { initial estimated time }}\right] \times 100
\end{gathered}
$$

All projects raw data for this study obtained and collected from Libyan Audit Bureau documents by researcher (M. A. Youssef and A.S.A.Gliah, personal communication, 2014), the projects sample comprised mainly infrastructure projects, airport construction projects, roadway projects, educational construction projects and House building projects. Projects documents collected and analyzed. The data used for the analyses collected by the researchers for 124 projects of varied size and type, most of them in Tripoli city and other regions. Each project data comprises the title, location, size, construction company type, actual construction start date, contract finish date, actual finish date, contract total project cost, and actual total project cost. The projects spread throughout many geographical locations in Libya, The projects documents data collected consisted of the costs and time changes made in associated projects. All 124 projects are public and distributed among most Libyan regions. The projects executed in 25 different Libyan regions. The projects were performed by different construction contractors "local or foreign" by two delivery system. Projects grouped according to used delivery system, and construction company nationality.

In this study, the quantitative data analysis done to examine and establish the effect of DB and DBB about projects time growth "time overrun" and cost growth "cost overrun". This study analyzed empirical project data from two samples. One sample contains 43 DB projects, represent $35 \%$ of total projects. Projects executed by local companies were 34 projects and 9 projects by foreign companies. The other sample $81 \mathrm{DBB}$ projects, represent $65 \%$ of total projects. Projects executed by local companies were 67 projects and 14 projects by foreign companies. 


\section{Findings and Discussions}

Projects attribute data identified project size, location, delivery method and company type. Objective measurement of cost and schedule metrics provided direct comparisons between DB and DBB project delivery systems. Analyses were used to measuring cost and schedule performance of project samples and perform an empirical comparison of DBB and DB with respect to project time change, and cost change. The analyses conducted to get a general sense of the type of projects delivery method and company type used for evaluations.



Figure 1. Project Volume Frequency performed by DB.

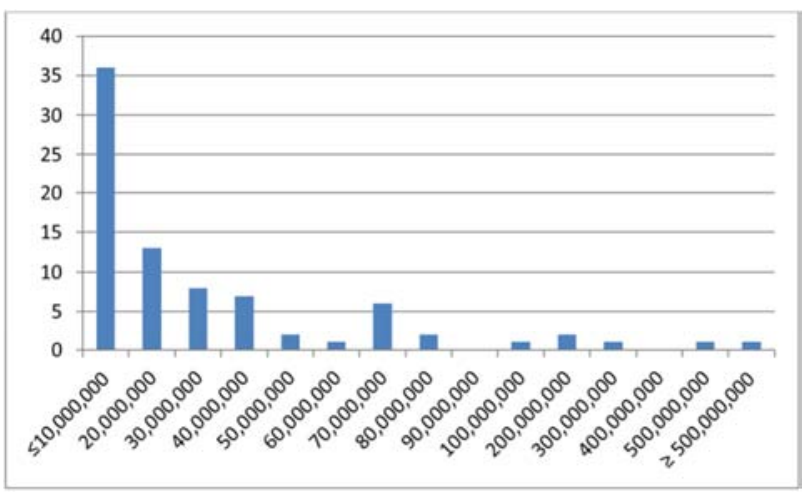

Figure 2. Project Volume Frequency performed by DBB.

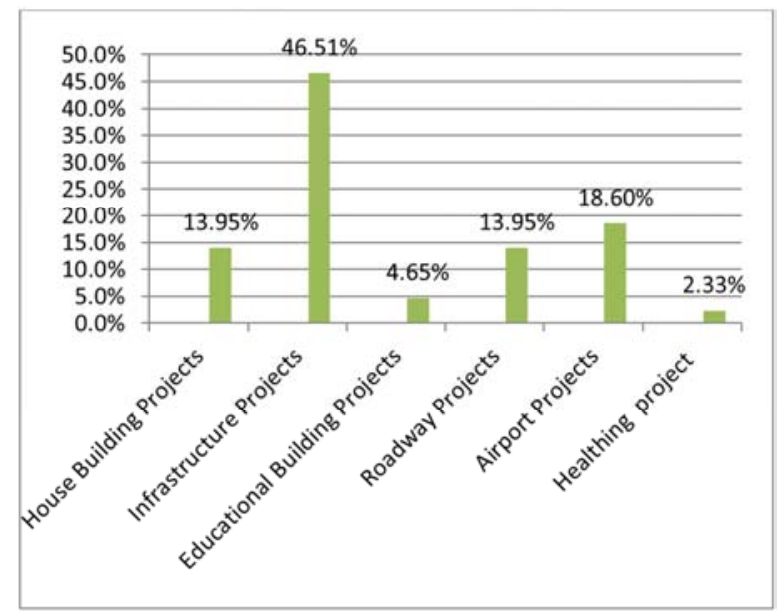

Figure 3. Survey Design-Build project type's percentage.

DB Most projects were between 10 million and 500 million Libyan Dinar according to their total cost. The majority of these projects were large, as shown in figure 1. DBB projects were between 10 million and 500 million Libyan Dinar as shown in figure 2. In addition, figure .3 showed and summarized the types of the $43 \mathrm{DB}$ projects frequency of occurrence. This shows infrastructure projects to be the dominant project type, followed by airport projects, roadway construction and maintenance projects and house building projects, the proportions of different project types were as follows:

(1) Infrastructure construction projects accounted for $46.51 \%$,

(2) Airport construction projects accounted for $18.6 \%$.

(3) Roadway construction projects $13.95 \%$.. Also, house building $13.95 \%$.

Figure 4 summarizes the types of the 81 DBB projects frequency of occurrence, house buildings was the dominant project type, followed by roadway construction and maintenance projects and infrastructure projects facilities, the proportions of different project types were as follows:

(1) House building projects $30.86 \%$,

(2) Roadway construction and maintenance projects $29.63 \%$,

(3) Infrastructure construction projects $24.69 \%$.

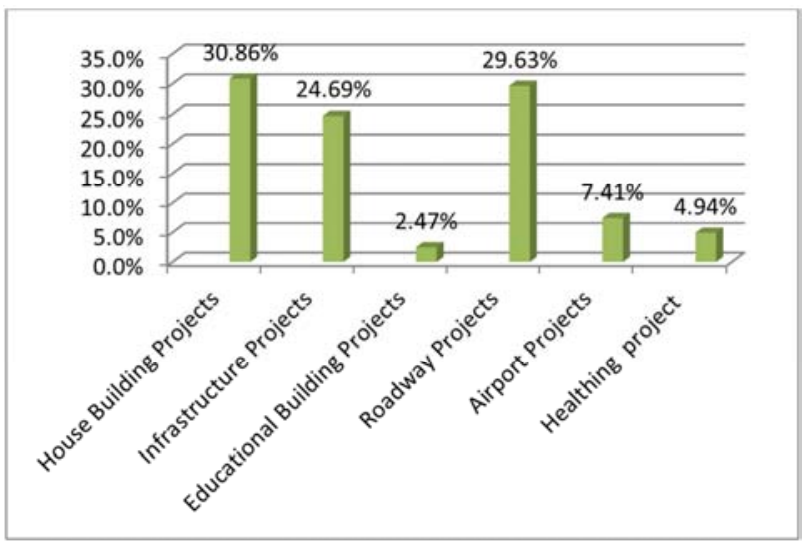

Figure 4. Survey Design-Bid-Build project type's percentage.

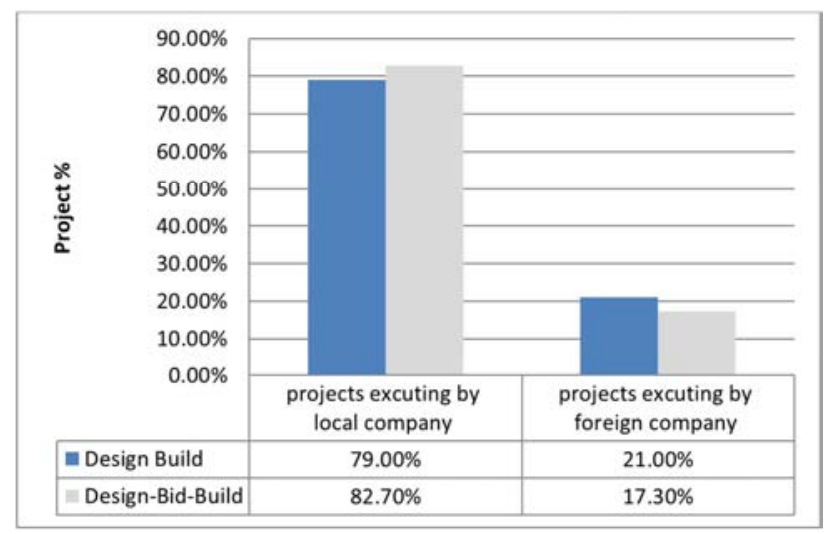

Figure 5. Projects distributed on local and foreign companies.

Figure 5, Showed the total projects executed by local Libyan construction companies were 101 projects by DB and DBB. In addition, total projects executed by foreign construction companies were 23 projects by DB and DBB. 
Local companies delivered 34 projects with $79 \%$ by DB system and 67 projects with $82.7 \%$ by DBB system. In addition, foreign construction companies delivered 9 projects with $21 \%$ by DB system and 14 projects with $17.3 \%$ by DBB system.

\subsection{Time Overrun Analysis}

Figure6present the distribution of the time overrun rates "schedule changes" for all projects performed by two delivery methods "DB, DBB" and two types of construction companies. Time overrun measures the change between the planned and actual project duration, as previously defined. By charting the percentage of projects to three divisions: firstly, whose completion schedule were on schedule or earlier. Secondly, whose completion schedule were within $25 \%$ above the planned schedule. Thirdly, whose completion schedule were exceeded $25 \%$ of the planned schedule. This figure reported $60.46 \%$ of all DB projects performed by local and foreign construction companies experienced $0 \%$ schedule change, nearly twice the reported for the DBB projects. Conversely, $53 \%$ of all DBB projects performed by two types of companies were more likely to exceed $25 \%$ of initial schedule, which is nearly twice the occurrence of the DB projects, also executed by two types of construction companies. For the range of within $25 \%$ above the planned schedule, the two percentages were equal $11.6 \%$ and $13.6 \%$ approximately for the two delivery system "DB" "DBB". From this view, the DB was better than DBB. Time extension for DB projects executed by local and foreign construction companies were $32 \%$ and $0 \%$ respectively as shown in figure 7 . Time overrun for DBB projects executed by local and foreign construction companies were $40 \%$ and $43 \%$ respectively. Therefore, foreign construction companies better than local construction companies in utilizing DB system, but in DBB system were not good.

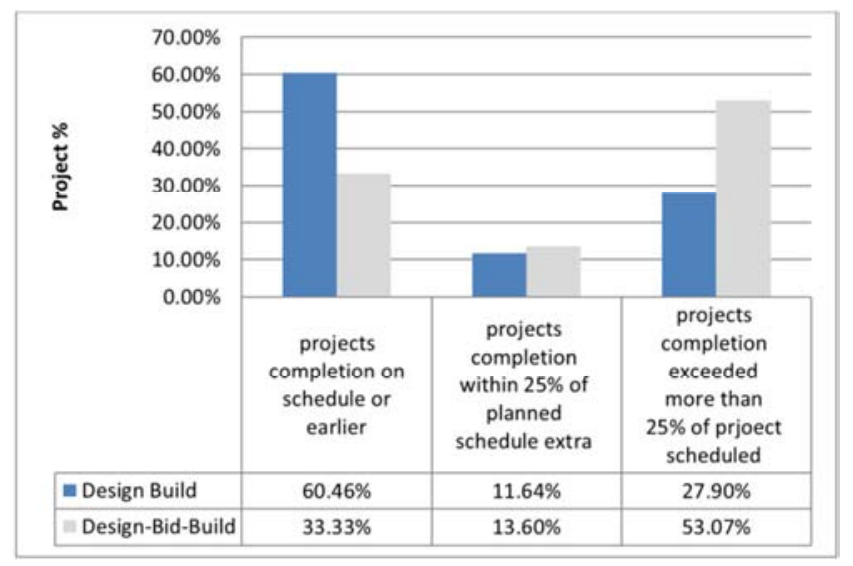

Figure 6. Project scheduling performance for $D B$ and $D B B$ projects.

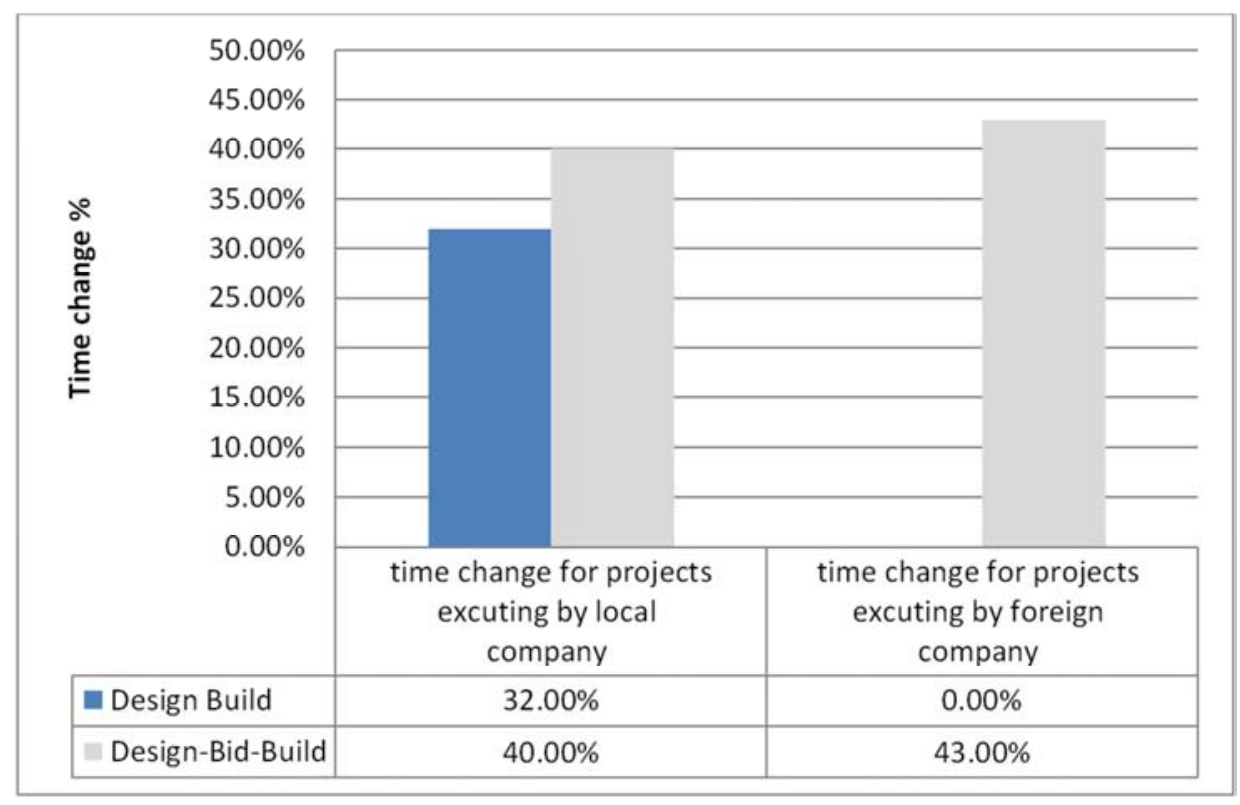

Figure 7. Schedulingchange rates for project executed by local and foreign companies.

\subsection{Costoverrun Analysis}

Cost changes metric occurred of project completion considered in three categories as shown in figure 8 , equal or below the initial budget, within $25 \%$ and above $25 \%$ the contracted project cost. Here, all DB projects nearly were three times more likely to project delivery on or below the contracted project cost than the all DBB projects executed by two types of construction companies. In addition, all DBB projects nearly were five times that reported for the design build, which project cost change above $25 \%$ of projects budget. From this view, the DB was better than DBB. Cost overrun for DB projects executed by local and foreign construction companies were $10 \%$ and $0 \%$ respectively as showed in figure 9. Cost changes for DBB projects executed by local and foreign construction companies were $34 \%$ and $26 \%$ respectively. Therefore, foreign construction companies were better than local construction companies in utilizing DB system and DBB system were. 


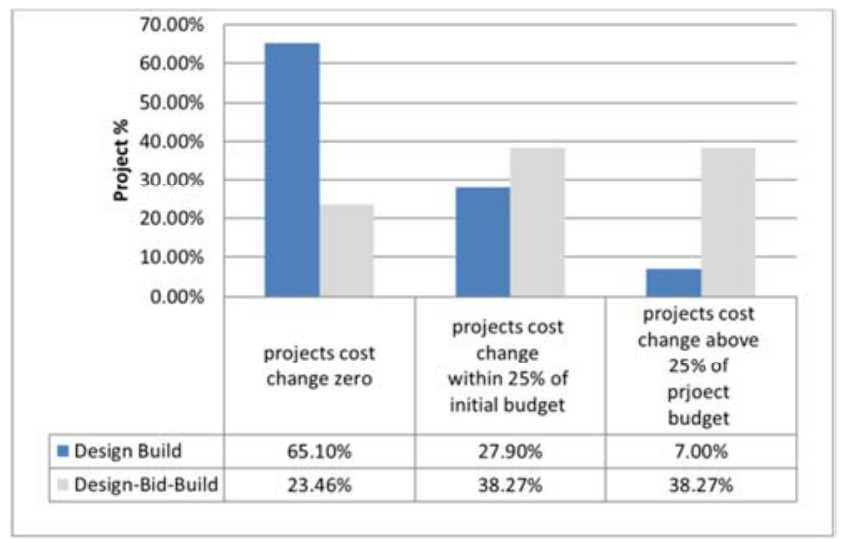

Figure 8. Project cost changes rates for $D B$ and $D B B$ projects.

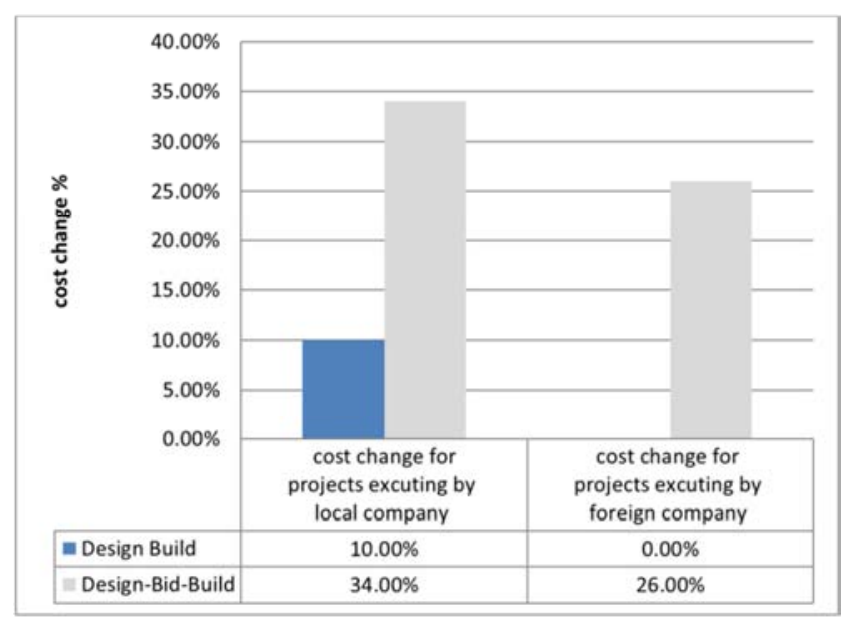

Figure 9. Cost change rates for project executed by local and foreign companies.

\section{Conclusions and Recommendations}

This study analyzed the time and cost performance indicators of real projects data from the Libyan Audit Bureau. By comparing the DBB with DB based on 124 Libyan projects (81DBB projects and 43 DB projects). The DBB projects which achieved by local and foreign construction companies have the average cost overrun $34 \%$, and $26 \%$ respectively. Whilst the average cost change for DB projects only $10 \%$ and $0 \%$ w.r.t. local and foreign companies respectively. The average time extension of the DBB projects that achieved by local and foreign construction companies was $39.8 \%$, and $43 \%$ respectively. The average time extension for DB projects $32 \%$ and $0 \%$ w.r.t. local and foreign companies respectively. Based on the results of the comparison, Design Build was beneficial for project time and cost at certain conditions especially when foreign companies used. In addition, local construction companies should be prequalified to use the DB system.

\section{Acknowledgment}

The authors would like to thank the Libyan Audit Bureau for providing the projects raw data files and information on which the paper was developed.

\section{References}

[1] American Institute of Architects. (1975). "Design-Bid-Build Task Force Report.” Washington D.C.

[2] Ibrahim Albalushi, Fathoni Usman and Ali S. Alnuaimi, (2013). "Construction Cost Overrun and Variations: Investigation on Its Causes and Consequences." Australian Journal of Basic and Applied Sciences, 7(14), Pages: 311-323.

[3] Saleh Al Hadi Tumi,Abdelnaser Omran and Abdul Hamid Kadir Pakir, (2009)“Causes Of Delay In Construction Industry In Libya.'Int. Conference on Economics and Administration, Faculty of Administration and Business, University of Bucharest, Romania, ICEA - FAA Bucharest.

[4] William Ibbs, and Ying-Yi Chih, (2011). "Alternative methods for choosing an appropriate project delivery system (PDS)." Facilities, Vol. 29 No. 13/14, pp. 527-541.

[5] Morris, S. (1990) "Cost and Time Overruns in Public Sector Projects." Economic and Political Weekly, Nov. 24, Vol. XXV, No. 47, pp. M154 -168.

[6] Lædre, O., Austeng, K., Haugen, T., and Klakegg, O. (2006). "Procurement routes in public building and construction projects." J. Constr. Eng. Manage., 10.1061/ (ASCE) 07339364, 132:7(689), 689-696.

[7] Assaf, S. A., and Al-Hejji, S. (2006). "Causes of delay in large construction projects.” Int. J. Project Manage., 24(4), 349-357.

[8] Irelend, V. (1984). "Virtually Meaningless Distinctions between Nominally Different Procurement Methods." Proceedings of 4thInt. Symposium on Organization and Management ofConstruction, Waterloo, Ontario, Canada, Vol. 1 pp.203-212.

[9] William Ibbs; Young Hoon Kwak; Tzeyu Ng; and A. Murat Odabasi, (2003). "Project Delivery Systems and Project Change: Quantitative Analysis.” J. Constr. Eng. Manage., Vol. 129, No. 4, Pages 382-387.

[10] Cingle III, George and John G Wachter (2010). "The Project DeliverySystem Rating Index (PDSRI)." Available at http://www.aist.org.

[11] Esmaeili, Behzad; Pellicer, Eugenio; and Molenaar, Keith R. (2014). "Critical Success Factors for Construction Projects." 18th Int. Congress on Project Management and Engineering, Alcañiz.

[12] Qing Chen; Zhigang Jin; Bo Xia; Peng Wu; and Martin Skitmore, (2015). "Time and Cost Performance of DesignBuild Projects." J. Constr. Eng. Manage., ASCE, ISSN 07339364/04015074(7).

[13] Konchar, M., and Sanvido, V. (1998). "Comparison of U.S. project delivery systems." J. Constr. Eng. Manage., 10.1061/(ASCE)0733-9364, 124:6(435), 435 - 444.

[14] Hale, D. R., Shrestha, P. P, Gibson, G. E., and Migliaccio, G. C. (2009). "Empirical comparison of design/build and design/bid/build project delivery methods." J. Constr. Eng. Manage., 10.1061/(ASCE)CO.1943-7862.0000017, 579-587.

[15] Memon, A. H., I. A. Rahman, M. R. Abdullah and A. A. Azis, (2011). "Time Overrun in Construction Projects from the Perspective of Project Management Consultant (PMC)." Journal of Surveying, Construction and Property, 2(1): 54-66. 